\title{
Asymptomatic posthaemodialysis femoral arteriovenous fistula: multidetector computed tomography (MDCT) evaluation and management
}

\author{
Priyank Yadav ${ }^{1}$ Sandeep Kumar Nunia, ${ }^{1}$ Dharamveer Singh, ${ }^{1}$ Hira Lal ${ }^{2}$
}

'Department of Urology and Renal Transplant, Sanjay Gandhi Postgraduate Institute of Medical Sciences, Lucknow, Uttar Pradesh, India ${ }^{2}$ Department of

Radiodiagnosis, Sanjay Gandhi Postgraduate Institute of Medical Sciences, Lucknow, Uttar Pradesh, India

\section{Correspondence to}

Dr Hira Lal,

hiralal2007@yahoo.co.in

Accepted 26 July 2016

\section{DESCRIPTION}

A 33-year-old man with end-stage renal disease underwent right femoral venous puncture by palpatory method for haemodialysis. Following puncture, there was profuse bleeding which was controlled with thrombin injection. Thereafter, he was asymptomatic. Four months later, during renal transplant workup, a prominent thrill was found at the site of femoral access. Doppler ultrasound demonstrated a fistula between the femoral artery and femoral vein. Multidetector computed tomography (MDCT) demonstrated the location of fistula (figure 1) for which he underwent surgical repair. Postoperative MDCT showed successful resolution of fistula (figure 2). The patient underwent renal transplantation in the right iliac fossa and at 1 year of follow-up, he is asymptomatic and serum creatinine is $1.0 \mathrm{mg} / \mathrm{dL}$.

Femoral vessels are commonly used for access during endovascular procedures and haemodialysis.
The incidence of femoral arteriovenous fistula is well documented after cardiac catheterisation and is around $1 \% .{ }^{1}$ Femoral arteriovenous fistula is rarely reported following femoral vein access for haemodialysis. The use of ultrasonography for access reduces the risk of inadvertent arterial injury. The presentation may vary from asymptomatic to lower limb ischaemia, cardiac failure or even graft dysfunction following renal transplantation. ${ }^{2}$ The modalities available for the assessment of arteriovenous fistula are colour Doppler (operator dependent), contrast MR angiography (time consuming and has risk of nephrogenic systemic fibrosis in dialysis-dependent patients) and catheter angiography (invasive and used if a radiological intervention is contemplated). MDCT is fast, non-invasive, iodinated contrast used is easily dialysable, reformatted images are easy to interpret and help in preoperative planning. Endovascular and open surgical techniques are successful in over $95 \%$ of the cases. ${ }^{3}$
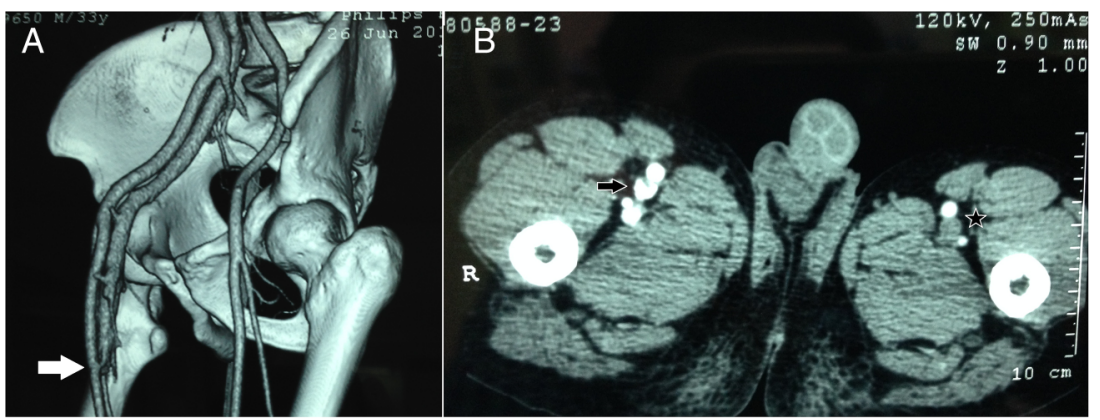

Figure 1 (A) Preoperative reformatted volume rendered image of CT angiography of pelvis and upper thigh showing fistulous communication between the femoral artery and the femoral vein (solid white arrow) with filling of right femoral and iliac veins. (B) CT angiography of upper thigh in axial plane showing contrast opacification of the femoral vein (solid black arrow). Normal left femoral vein for comparison (black star).
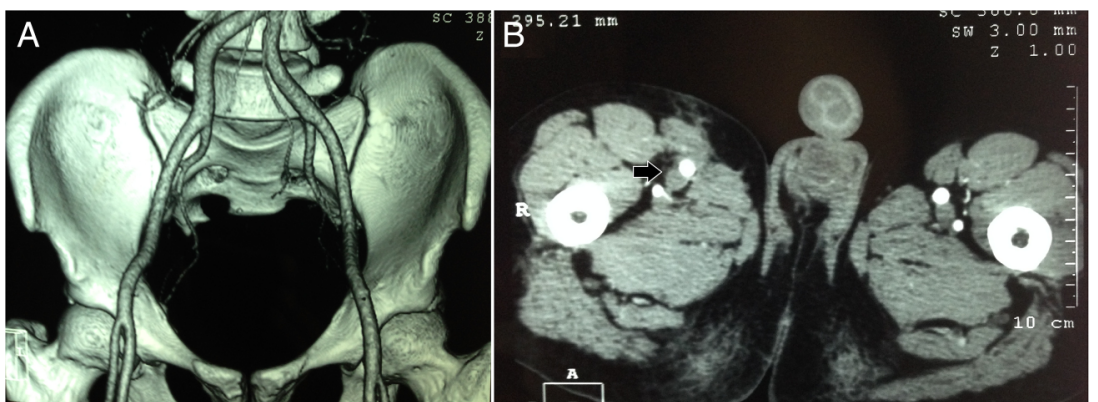

Singh $\mathrm{D}$, et al. BMJ Case Rep Published online: [please include Day Month Year] doi:10.1136/bcr-2016216947

Figure 2 (A) Postoperative reformatted volume rendered image of CT angiography of the pelvis showing non-filling of the right femoral and common iliac veins. (B) CT angiography of upper thigh in axial plane at the same level as figure $1 \mathrm{~B}$ showing non-opacification of the right femoral vein (solid black arrow). 


\section{Learning points}

- Femoral vein is a common site for vascular access during haemodialysis especially in acute setting.

- Owing to the proximity of the femoral artery to the femoral vein, sometimes, a puncture may lead to iatrogenic communication between the two forming a fistula.

- Multidetector computed tomography helps in detailed assessment of the surgical anatomy as well as aids in surgical planning for minimally invasive or open procedure.

Contributors $\mathrm{HL}$ contributed to the conception of the study, SKN participated in the study design, DS performed literature search and data acquisition, PY involved in manuscript preparation, $\mathrm{HL}$ and SKN involved in manuscript editing, $\mathrm{HL}$ and PY contributed to manuscript review and HL is the guarantor.

Competing interests None declared.

Patient consent Obtained.

Provenance and peer review Not commissioned; externally peer reviewed.

\section{REFERENCES}

1 Kelm M, Perings SM, Jax T, et al. Incidence and clinical outcome of iatrogenic femoral arteriovenous fistulas: implications for risk stratification and treatment. J Am Coll Cardiol 2002;40:291-7.

2 Özdemir-van Brunschot DM, de Sévaux RG, van Hamersvelt HW, et al. Outcome of kidney allografts in recipients with a femoral arteriovenous fistula: report of two cases. Urol Case Rep 2016;8:21-3.

3 Linder F. Acquired arterio-venous fistulas. Report of 223 operated cases. Ann Chir Gynaecol 1985;74:1-5.

Copyright 2016 BMJ Publishing Group. All rights reserved. For permission to reuse any of this content visit http://group.bmj.com/group/rights-licensing/permissions.

BMJ Case Report Fellows may re-use this article for personal use and teaching without any further permission.

Become a Fellow of BMJ Case Reports today and you can:

- Submit as many cases as you like

- Enjoy fast sympathetic peer review and rapid publication of accepted articles

- Access all the published articles

- Re-use any of the published material for personal use and teaching without further permission

For information on Institutional Fellowships contact consortiasales@bmjgroup.com

Visit casereports.bmj.com for more articles like this and to become a Fellow 